\title{
Factors Affecting Non-Performing Financing at Islamic Commercial Banks in Indonesia
}

\author{
Ayu Retnowati*1 and Prabowo Yudo Jayanto ${ }^{2}$ \\ ${ }^{1,2}$ Accounting Department, Faculty of Economics, Universitas Negeri Semarang
}

\begin{tabular}{l} 
ARTICLE INFO \\
\hline Article History: \\
Received January $18^{\text {th }}, 2018$ \\
Accepted March $3^{\text {th }}, 2020$ \\
Available March $30^{\text {th }}, 2020$ \\
\hline Keywords: \\
capital adequacy ratio; \\
financing to deposit ratio; \\
gross domestic product; \\
inflation; non performing \\
financing; operational income \\
operating cost
\end{tabular}

\section{ARTICLE INFO}

\section{Article History:}

Received January $18^{\text {th }}, 2018$

Accepted March $3^{\text {th }}, 2020$

Keywords:

capital adequacy ratio; financing to deposit ratio; operating cost

\begin{abstract}
This study aims to determine the effect of Inflation, Gross Domestic Product (GDP), Operational Income Operating Cost (BOPO), Financing to Deposit Ratio (FDR) and Capital Adequacy Ratio (CAR) to Non Performing Financing (NPF). The population in this study were 13 Islamic Commercial Bank in Indonesia in year 2012-2015. The sample selection used purposive sampling technique which resulted in 9 banks and the analysis units were 36. Data collection method used in this research was documentation. Data analysis method used was Structural Equation Modeling (SEM) with Partial Least Square (PLS) with SmartPLS 3.0 analysis tool. The results show that the inflation, GDP, and FDR variables do not significantly influence NPF. BOPO variable has a positive and significant influence to NPF. CAR variable has a negative and significant influence to NPF. The conclusion shows that the inflation, GDP, and FDR variables do not significantly influence NPF. Variables of BOPO and CAR have significant influence to NPF.
\end{abstract}

\section{INTRODUCTION}

Financing is a form of distribution of funds provided by Islamic banks to the public who need funds. Asrori (2014) stated Islamic banks are Islamic financial institutions, which were founded based on belief in Islamic teachings and adherence to Islamic principles. In financing at Islamic commercial banks, there is a risk of financing, namely non-performing financing. Non Performing Financing is a non-performing financing indicator that needs to be considered because it is fluctuating and uncertain, so it is important to observe with special attention. NPF is one of the performance assessment instruments of an Islamic bank which is an interpretation of the assessment of productive assets, especially in the assessment of non-performing financing (Popita, 2013).

Non Performing Financing shows the ability of bank management to manage non-performing financing provided by banks. The higher this ratio, the worse the quality of bank loans which causes increased problem loans (Yulianto \& Solikhah, 2016). Non-performing Fi-

*E-mail: aretnowati33@gmail.com

_Address: L2 Building 2nd floor, Campus Sekaran, Gunungpati, Semarang, Indonesia, 50229 nancing (NPF) financing consists of Substandard (KL), Loss (M) and Doubtful (D) financing.

High financing growth is also accompanied by deteriorating financing quality, which can be seen from the higher NPF in Islamic banks than NPLs in conventional banks. Quoted from the okezone.com news page (2017) that the Financial Services Authority (OJK) states if the financing ratio is the ratio of Non Performing Finance / NPF) from Islamic banks is still relative higher compared to conventional banks' Non-Performance Loans (NPLs). Noted, from the fourth quarter of 2016 to October 2017 the NPF value of Islamic banks was at $4.12 \%$. This figure far exceeds the conventional bank NPL of $2.96 \%$. This can be seen in the following table:

Table1. Comparison of NPF in Islamic Commercial Banks and Conventional Bank

\begin{tabular}{ccc}
\hline Years & $\begin{array}{c}\text { Islamic Bank } \\
\text { NPF (\%) }\end{array}$ & $\begin{array}{c}\text { Conventional Bank } \\
\text { NPL (\%) }\end{array}$ \\
\hline 2012 & 2.22 & 1.87 \\
2013 & 2.62 & 1.80 \\
2014 & 4.95 & 2.04 \\
2015 & 4.84 & 2.39 \\
2016 & 4.12 & 2.96 \\
2017 (Oct) & 4.12 & 2.96 \\
\hline
\end{tabular}

Source : OJK www.ojk.go.id), 2017

p-ISSN 2252-6765 e-ISSN 2502-6216 
The statistical data listed in table 1 is known that the NPF value of Islamic banks is higher than conventional bank NPLs from 2012 to 2017. The high value of NPF in Islamic banks attracts the researchers to examine the factors that can affect Non Performing Financing (NPF) at Islamic commercial banks. The variables examined in this study are inflation, Gross Domestic Product (GDP), Operational Income Operating Cost (BOPO), Financing to Deposit Ratio (FDR), and Capital Adequacy Ratio (CAR).

Previous research searches still show inconsistent results for inflation, GDP, BOPO, FDR and CAR variables in their effects on the NPF, so a research gap is found. Yasin \& Widiastuti (2014), Nasih (2013) and Iriani \& Yuliadi (2015) stated that inflation has a significant positive effect on Non-Performing Financing (NPF), whereas Firmansari \& Suprayogi (2015) and Effendi, Thiarany, \& Nursyamsiah (2017) stated that inflation has a significant negative effect on Non Performing Financing (NPF). Meanwhile, Lidyah (2016)Biaya Operasional Pendapatan Operasional (BOPO, Asnaini (2014), Akbar (2016)dan Financing to Deposit Ratio (FDR, and Havidz \& Setiawan (2015)the determinants of banks efficiency and non-performing financing (NPF stated inflation does not have a significant effect on Non Performing Financing (NPF).

Gross Domestic Product (GDP) examined by Firmansari \& Suprayogi (2015), Effendi et al. (2017), and Havidz \& Setiawan (2015)the determinants of banks efficiency and non-performing financing (NPF showed a significant positive effect on Non Performing Financing (NPF), whereas Akbar (2016)dan Financing to Deposit Ratio (FDR, Yasin \& Widiastuti (2014), Firmansyah (2014), Haryono, Mohd, \& Hamat (2016), and Kusmayadi, Firmansyah, \& Badruzaman (2017) stated Gross Domestic Product (GDP) has a significant negative effect on Non-Performing Financing (NPF). Meanwhile, Asnaini (2014) and Mutamimah \& Chasanah (2012) stated Gross Domestic Product (GDP) does not have a significant effect on Non Performing Financing (NPF).

Operational Income Operating Cost (BOPO) examined by Lidyah (2016)Biaya Operasional Pendapatan Operasional (BOPO and Effendi et al. (2017) showed a significant positive effect on Non Performing Financing (NPF), whereas Suryanto (2015) and Setiawan, Hasan, Hassan, \& Mohamad (2017) stated Operational Income Operating Cost (BOPO) has a significant negative effect on Non-Performing Financing (NPF). Meanwhile, Firmansyah (2014) and Raysa (2013) stated Operational Income Operating Cost (BOPO) has no significant effect on Non-Performing Financing (NPF).

Financing to Deposit Ratio (FDR) examined by Haifa \& Wibowo (2015), Sari (2016) and Firmansyah (2014) showed a significant positive effect on Non Performing Financing (NPF), whereas Akbar (2016)dan Financing to Deposit Ratio (FDR, Setiawan \& Sherwin (2017) and Farika et al. (2018) stated Financing to Deposit Ratio (FDR) has a significant negative effect on Non Performing Financing (NPF). Meanwhile, Firmansari \& Suprayogi (2015), Asnaini (2014), Yasin \& Widiastuti (2014) and Havidz \& Setiawan (2015)the determi- nants of banks efficiency and non-performing financing (NPF stated Financing to Deposit Ratio (FDR) has no significant effect on Non Performing Financing (NPF).

Capital Adequacy Ratio (CAR) examined by Firdaus (2015) and Farika et al. (2018) showed a significant positive effect on Non Performing Financing (NPF), whereas Akbar (2016)dan Financing to Deposit Ratio (FDR, Asnaini (2014), Effendi et al. (2017) and Lidyah (2016)Biaya Operasional Pendapatan Operasional (BOPO stated Capital Adequacy Ratio (CAR) has a significant negative effect on Non Performing Financing (NPF). Meanwhile, Havidz \& Setiawan (2015)the determinants of banks efficiency and non-performing financing (NPF and Haifa \& Wibowo (2015) stated Capital Adequacy Ratio (CAR) has no significant effect on Non Performing Financing (NPF). The existence of the research gap above provides an opportunity for researchers to re-examine the factors that influence Non-Performing Financing (NPF) with different samples.

The purpose of this study is to analyze the effect of inflation, GDP, BOPO, FDR and CAR on NonPerforming Financing (NPF). The originality of this study is to re-analyze the factors that influence NonPerforming Financing (NPF). The difference found in this study lies in the research year 2012-2015. Research references used include research conducted by (Akbar, 2016)dan Financing to Deposit Ratio (FDR and (Lidyah, 2016)Biaya Operasional Pendapatan Operasional (BOPO. Based on these studies, the independent variables that will be used in this study are inflation, GDP, BOPO, FDR, and CAR.

This research is based on the theory of Non Performing Financing (NPF). The term of "non-performing financing" in Islamic banking is the equivalent of the term of "non-performing loan" in conventional banking. The term non-performing loan has been commonly used by the world of Indonesian banking as a translation of problem loan or Non-Performing Loan (NPL) which is a term that is also commonly used in international banking (Wangsawidjaja, 2012). However, in Islamic Banking Statistics published by the Directorate of Islamic Banking Bank Indonesia, it is found the term Non Performing Financing (NPF) or in the Sharia Banking Dictionary is called duyunun ma'dumah, which is defined as "Non-current Financing from substandard to non-performing". Thus, it can be concluded that NonPerforming Financing is financing which quality is in the substandard class (class III), doubtful (class IV), and loss (class V). The Non-performing Financing in terms of productivity (performance), which is in relation to the ability to generate income for banks, has decreased even no longer exists (Wangsawidjaja, 2012).

The distribution of financing provided by the bank to the debtor will not always run as expected in the agreement. The failure of repayment of a portion of the financing provided and become non-performing financing so that it affects bank income. External (macro) and internal (micro) environmental conditions from the customer or debtor side and from the bank side can influence the smoothness of the debtor's obligations to the bank so that the financing that has been channelled to 
the debtor has the potency or causes failure. According to Wangsawidjaja (2012), non-performing loan is caused by customers not being able to fulfil their obligations to banks due to customer internal factors, bank internal factors, and / or due to external factors of the bank and customers.

Inflation is generally defined as an increase in the price of goods and services as a result of the amount of money (demand) that is greater than the amount of goods or services available (supply), as a result of inflation is a decrease in the value of money. According to Firmansyah (2014), inflation will affect economic activities both macro and micro including investment activities. Inflation also causes a decrease in people's purchasing power which results in a decrease in sales. Decreased sales that occur can reduce corporate returns. Decreased returns that occur will affect the ability of company to pay credit instalments. Instalment payments which are increasingly inappropriate make credit quality worse and even bad credit occur (Firmansyah, 2014).

According to NPF theory, inflation is one of the macroeconomic variables that can affect NPF. The Bank Indonesia Dictionary explains that inflation is an economic condition characterized by a rapid rise in prices so that it has an impact on decreasing purchasing power, often also followed by a decrease in the level of savings and / or investment due to increased public consumption and only a little for long-term savings so that it can cause customers difficulty in paying installments of financing to the bank. This assumption is supported by studies conducted by Yasin \& Widiastuti (2014) and Nasih (2013) state that inflation has a significant positive effect on Non Performing Financing (NPF).

\section{$H_{1}$ : Inflation has a significant positive effect on NPF.}

Gross Domestic Product (GDP) used to measure all goods and services produced in a state economy in a certain period. In relation to non-performing loans, in a recession (as seen from the decline in GDP) where there is a decrease in corporate sales and income, it will affect the company's ability to repay loans. This will cause an increase in non-current credit outstanding. Meanwhile, when GDP increases in theory there is an increase in economic transactions so that non-performing financing falls.

According to NPF theory, Gross Domestic Product (GDP) is one of the macroeconomic variables that can affect NPF. Firmansyah (2014) revealed that GDP means measuring the market value of final goods and services produced by resources that are in a country for a certain period, usually one year. Where when GDP increases, the income earned by customers also increases, the risk of NPF will decrease. This is supported by research conducted by Akbar (2016)dan Financing to Deposit Ratio (FDR, Firmansyah (2014), Havidz \& Setiawan (2015)the determinants of banks efficiency and non-performing financing (NPF, Haryono et al. (2016) and Kusmayadi et al. (2017) which state that GDP has a negative effect on NPF.

\section{$\mathrm{H}_{2}$ : GDP has a significant negative effect on NPF.}

$\mathrm{BOPO}$ in Islamic Banks is known better as costs and revenues from profit sharing activities. If the BOPO level is high, bank management will be increasingly inefficient, causing high financing risks (NPF). The operational burden that must be borne by the bank will get bigger, which will have an impact on reducing the income earned by the bank. Declining income also reflects the smaller reserves of funds that banks can provide to cover problematic financing. The higher the $\mathrm{BOPO}$ ratio, the quality of financing will decrease; it also causes an increase in the ratio of non-performing financing. This is due to the higher the BOPO ratio, the less income earned by banks. The main income of the bank itself is obtained from the profit sharing of financing that has been distributed. Small income indicates that the quality of financing in the bank is reduced.

According to NPF theory, Operational Income Operating Cost (BOPO) is one of the micro variables that can affect NPF. A high BOPO value means that the costs incurred by the bank are more than the income earned, indicating that the quality of financing is poor thus giving rise to NPF. This is supported by research conducted by Lidyah (2016)Biaya Operasional Pendapatan Operasional (BOPO and Effendi et al. (2017) which state that BOPO has a significant positive effect on NPF.

\section{$\mathrm{H}_{3}$ : BOPO has a positive significant effect on NPF}

FDR will show the level of ability of Islamic banks in distributing third party funds collected by the Islamic banks concerned. The higher the Financing to Deposit Ratio (FDR), it is likely that the amount of funding to be provided will increase. On the other hand, the more amount of financing provided will cause quite high risk to the distribution of funds. With the existence of time limit on returning a credit loan, so the loaned credit will become problematic.

According to NPF theory, Financing to Deposit Ratio (FDR) is one of the micro variables that can affect NPF. Financing to Deposit Ratio (FDR) states how far the bank's ability to repay funds withdrawals by depositors by relying on loans provided as a source of liquidity (Popita, 2013). According to Akbar (2016)dan Financing to Deposit Ratio (FDR, the higher this ratio the lower the bank's liquidity capability. This assumption is consistent with research conducted by Haifa \& Wibowo (2015), Firmansyah (2014), Sari (2016) and Setiawan \& Sherwin (2017) stated that Financing to Deposit Ratio (FDR) has a positive effect on Non-Performing Financing (NPF) in Islamic banks in the short and long term.

\section{$\mathrm{H}_{4}$ : FDR has a significant positive effect on NPF.}

The decrease in CAR is a result of a decrease in the amount of bank capital or an increase in the number of Risk Weighted Assets (RWA). The small amount of bank capital is caused by a decrease in profits earned by the company. Decreased profit at banks one of which occurs due to an increase in non-performing loan or poor credit quality (Asnaini, 2014). Then the higher the CAR, the greater the ability of banks to minimize the risk of financing that occurs. 
According to NPF theory, Capital Adequacy Ratio (CAR) is one of the micro variables that can affect NPF. Capital Adequacy Ratio (CAR) is a capital ratio that shows the ability of banks to provide funds for business development needs and to accommodate the possible risk of losses resulting from bank operations. The greater the ratio, the better the capital position. A large capital ratio can minimize the occurrence of NPF because the bank has sufficient loss reserves. This is supported by research conducted by Lidyah (2016)Biaya Operasional Pendapatan Operasional (BOPO and Akbar (2016) dan Financing to Deposit Ratio (FDR which state that CAR has a significant negative effect on non-performing financing (NPF).

\section{$\mathrm{H}_{5}$ : CAR has a significant negative effect on NPF.}

Based on the description above, the research model in this study is shown in the following figure:

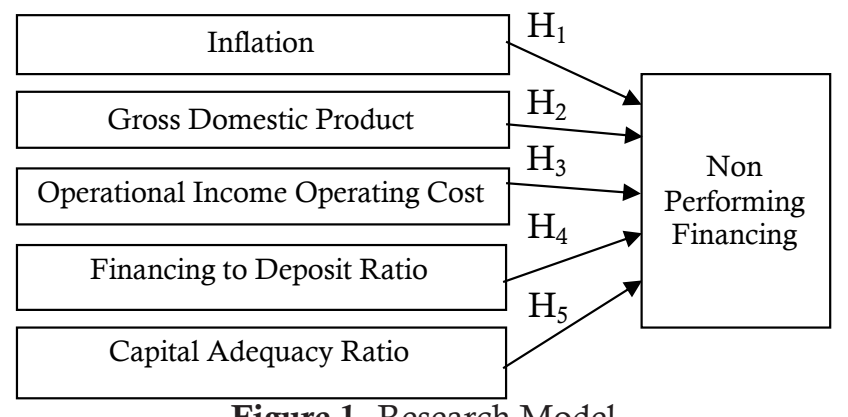

Figure 1. Research Model

\section{RESEARCH METHOD}

The type of research was quantitative research with a hypothesis testing research design study. The data used was secondary data. The population in this study was Islamic Commercial Banks in Indonesia for the period 2012-2015 amounting to 13 banks. The sampling technique used in this study was a purposive sampling technique obtained the final sample of 9 banks with a 4-year observation period resulting in 36 units of analysis. Determination of the sample based on the criteria can be seen in Table 2 .

Table 2. Sample criteria

\begin{tabular}{llc}
\hline No $\quad$ Sample Criteria & $\begin{array}{c}\text { Beyond } \\
\text { criteria }\end{array}$ & Samples \\
\hline & $\begin{array}{l}\text { Islamic Commercial Banks } \\
\text { must provide complete fi- }\end{array}$ & 13 \\
nancial reports for the period & (3) & 10 \\
2012-2015. & \\
The financial statements \\
provided are annual finan- \\
cial statements for the period \\
2012-2015 that have been pub- \\
$\begin{array}{l}\text { lished at Bank Indonesia or on } \\
\text { the websites of the respective }\end{array}$
\end{tabular}

Endogenous variable in this study was Non Performing Financing (NPF). Exogenous variables in this study are Inflation, Gross Domestic Product (GDP), Operational Income Operating Cost (BOPO), Finan-

Table 3. Operational Definition of Variables

\begin{tabular}{|c|c|c|}
\hline Research Variable & Definition & Measurement \\
\hline $\begin{array}{l}\text { Endogenous } \\
\text { Variable (Y): } \\
\text { Non Performing } \\
\text { Financing (NPF) }\end{array}$ & $\begin{array}{l}\text { The ratio between the amount of financing provided } \\
\text { and the level of collectability (substandard, doubtful, } \\
\text { and loss) compared to the total financing provided by } \\
\text { the bank (Akbar, 2016) }\end{array}$ & $\begin{array}{c}N P F=\frac{\text { Non }- \text { Performing Financing }}{\text { Total Financing }} \times 100 \\
(\text { Akbar,2016) }\end{array}$ \\
\hline $\begin{array}{l}\text { Exogenous } \\
\text { Variables (X): } \\
\text { X1; Inflation }\end{array}$ & $\begin{array}{l}\text { The increase of the level of prices of goods and ser- } \\
\text { vices continuously (Akbar, 2016) }\end{array}$ & $\begin{aligned} \text { Inflation }= & \frac{I H K_{t}-I H K_{t-1}}{I H K_{t-1}} \times 100 \% \\
& (\mathrm{Akbar}, 2016)\end{aligned}$ \\
\hline $\begin{array}{l}\mathrm{X} 2 ; \text { Gross Domestic } \\
\text { Product }(G D P)\end{array}$ & $\begin{array}{l}\text { The total money value of all goods and services pro- } \\
\text { duced in an economy during one period (Popita, } \\
\text { 2013). }\end{array}$ & $\begin{aligned} \text { Growth of } G D P \\
=\frac{G D P_{t}-G D P_{t-1}}{G D P_{t-1}} \times 100 \% \\
(\text { Popita }, 2013)\end{aligned}$ \\
\hline $\begin{array}{l}\text { X3; Operational } \\
\text { Income Operating } \\
\text { Cost (BOPO) }\end{array}$ & $\begin{array}{l}\text { Efficiency ratio is used to measure the ability of bank } \\
\text { management in controlling operational costs to oper- } \\
\text { ating income (Lidyah, 2016). }\end{array}$ & $\begin{aligned} B O P O= & \frac{\text { Operating Cost }}{\text { Operational Income }} \\
& (\text { Lidyah, 2016) }\end{aligned}$ \\
\hline $\begin{array}{l}\mathrm{X} 4 \text {; Financing to } \\
\text { Deposit Ratio (FDR) }\end{array}$ & $\begin{array}{l}\text { The ratio between the amount of funding disbursed to } \\
\text { the total DPK (Akbar, 2016)dan Financing to Deposit } \\
\text { Ratio (FDR. }\end{array}$ & $\begin{array}{c}\text { FDR }=\frac{\text { Total Financing }}{\text { Third Party Funds }} \times 100 \% \\
\quad(\text { Akbar, 2016) }\end{array}$ \\
\hline $\begin{array}{l}\text { X5; Capital Adequacy } \\
\text { Ratio (CAR) }\end{array}$ & $\begin{array}{l}\text { The ratio between bank capital to risk-weighted assets } \\
\text { (Akbar, 2016)dan Financing to Deposit Ratio (FDR. }\end{array}$ & $\begin{aligned} C A R= & \frac{\text { Bank Capital }}{(R W A)} \times 100 \% \\
& (\text { Akbar, 2016) }\end{aligned}$ \\
\hline
\end{tabular}


cing to Deposit Ratio (FDR) and Capital Adequacy Ratio (CAR). The explanation of the operational definition of each variable is presented in Table 3 .

The technique of data collection was done by the documentation method on the annual financial statements of Islamic Commercial Bank recorded on the website of each bank. The data analysis method used in this research was descriptive statistical analysis using SmartPLS version 3.0. Data analysis technique used was the measurement model test (outer model), structural model test (inner model) and hypothesis testing.

\section{RESULTS AND DISCUSSIONS}

Descriptive statistics are performed to provide a descriptive explanation of data consisting of average, standard, maximum, and minimum deviations on the variables of inflation, GDP, BOPO, FDR and CAR. The descriptive statistical test results are presented in Table 4.

The next test is the outer model test, inner model test and hypothesis test. The outer model test is used to test the validity and reliability. Data is said to be valid if the loading factor value is more than 0.50 . The test results show that the data in this study are valid because they have a loading factor of 1.00 .

PLS-SEM using the SmartPLS 3.0 program to measure the reliability of a construct with reflective indicators can be done in two ways, namely by looking at the value of Cronbach's Alpha and Composite Reliability. The construct is declared reliable if the values of Cronbach's Alpha and Composite Reliability are above
0.70 . The result of the reliability test shows a number of 1.00 which means that the composite reliability and cronbach's alpha values of all constructs are above 0.70 . This value indicates that the consistency and stability of the instruments used are very high, so the construct or variable in this research model has become a fit measurement tool. Thus, it can be concluded that each construct used in this research model has a high level of reliability.

The inner model or structural model testing is done to see the relationship between constructs, significant values, and R-square of the research model. The R-Square value of the endogenous variable Non Performing Financing (NPF) is 0.331 . This value can be interpreted that the variability of Non Performing Financing (NPF) which can be explained by the construct in the study amounted to $33.1 \%$, while the other $66.9 \%$ is explained by other variables not examined in this research model. In conclusion, that the endogenous variable is moderate because it has an R-Square value of 0.33 .

Hypothesis testing is done by looking at the value of the path coefficient which shows the parameter coefficient and the t-statistic value. Parameter significant which is estimated provide information about the relationship between the variables in the study then compare $t$-statistic value with $t$-table value. If the $t$-statistic is higher than the t-table value, it means that the hypothesis is supported or accepted. In this study for a 95 percent confidence level (alpha 95 percent), the T-statistic value is above 1.684 for $p \leq 0.05$ (one tailed) and 1.96 for $p \leq 0.05$ (two tailed). The summary of the hypothesis result is presented in table 5 .

Table 4. Results of Descriptive Statistics Test

\begin{tabular}{cccccc}
\hline No & Variables & Mean Values & Standard Deviation & Maximum Values & Minimum Values \\
\hline 1 & NPF & 1.363 & 1.342 & 4.588 & 0.017 \\
2 & Inflation & 6.097 & 2.297 & 8.380 & 3.350 \\
3 & GDP & 5.375 & 0.449 & 6.000 & 4.900 \\
4 & BOPO & 83.401 & 13.394 & 114.145 & 47.695 \\
5 & FDR & 93.625 & 8.766 & 123.801 & 79.862 \\
6 & CAR & 18.003 & 6.019 & 34.328 & 11.102 \\
\hline
\end{tabular}

Source: Secondary data processed, 2017

Table 5. Summary of Hypothesis Results

\begin{tabular}{|c|c|c|c|c|c|}
\hline Hypothesis & Statements & Coefficient & T-statistic & P-Values & Results \\
\hline $\mathrm{H}_{1}$ & $\begin{array}{l}\text { Inflation has a significant positive effect on Non } \\
\text { Performing Financing (NPF) }\end{array}$ & -0.140 & 0.895 & 0.186 & Rejected \\
\hline $\mathrm{H}_{2}$ & $\begin{array}{l}\text { Gross Domestic Product (GDP) has a significant } \\
\text { negative effect on Non-Performing Financing } \\
\text { (NPF)) }\end{array}$ & -0.234 & 1.418 & 0.078 & Rejected \\
\hline $\mathrm{H}_{3}$ & $\begin{array}{l}\text { Operational Income Operating Cost (BOPO) has } \\
\text { a significant positive effect on Non Performing Fi- } \\
\text { nancing (NPF) }\end{array}$ & 0.295 & 2.140 & 0.016 & Accepted \\
\hline $\mathrm{H}_{4}$ & $\begin{array}{l}\text { Financing to Deposit Ratio (FDR) has a signifi- } \\
\text { cant positive effect on Non Performing Financing } \\
\text { (NPF) }\end{array}$ & 0.124 & 0.807 & 0.210 & Rejected \\
\hline $\mathrm{H}_{5}$ & $\begin{array}{l}\text { Capital Adequacy Ratio (CAR) has a significant } \\
\text { negative effect on Non Performing Financing } \\
\text { (NPF) }\end{array}$ & -0.409 & 4.330 & 0.000 & Accepted \\
\hline
\end{tabular}


The Effect of Inflation on Non Performing Financing (NPF)

The result of statistical test shows that inflation has no significant effect on Non-Performing Financing (NPF), so the hypothesis is rejected. This can be interpreted that the size of inflation does not affect the Non Performing Financing (NPF). The result of this study is not in line with the NPF theory which states that economic conditions which are characterized by rapidly rising prices that have an impact on declining purchasing power, often also followed by a decrease in the level of savings and or investment. This is due to increased public consumption and only a little for long term savings so that it can cause customers difficulty in paying instalment financing to banks.

The result of this study is in line with the previous studies conducted by Akbar (2016)dan Financing to Deposit Ratio (FDR, Lidyah (2016)Biaya Operasional Pendapatan Operasional (BOPO, Havidz \& Setiawan (2015)the determinants of banks efficiency and nonperforming financing (NPF and (Lin, Farhani, \& Koo, 2016) which state that inflation does not affect NonPerforming Financing (NPF) at Islamic Commercial Banks. This hypothesis is rejected because the Sharia Commercial Bank has stronger endurance compared to Conventional Banks. Islamic banks use several types of contracts that are more in financing that aim to diversify credit risk. The most dominant financing used is financing with a murabahah contract. In murabahah application, instalments are fixed from the beginning to the end, so when there is an increase in inflation in the long term. This does not affect the amount of instalments paid by customers. Because customers can plan cash flow arrangements needed to pay off murabahah financing, so the impact of financing risks can still be controlled.

\section{The Effect of Gross Domestic Product (GDP) on Non-Performing Financing (NPF)}

The result of statistical test shows that Gross Domestic Product (GDP) has no significant effect on Non-Performing Financing (NPF), so the hypothesis is rejected. This can be interpreted that the size of the Gross Domestic Product (GDP) does not affect the level of Non Performing Financing (NPF) at Islamic commercial banks in Indonesia. The result of this study is not in accordance with the NPF theory which states that GDP can measure the market value of final goods and services produced by resources that are in a country for a certain period of time, usually one year. Where when GDP increases, the income earned by customers also increases, the risk of NPF will decrease.

The result of this study is in line with the research conducted by Asnaini (2014) and Mutamimah \& Chasanah (2012) which state that Gross Domestic Product (GDP) has no significant effect on Non-Performing Financing (NPF). The rejection of this hypothesis is due to the condition of Islamic banks which are more resistant to macroeconomic variables. It is proven during a recession and crisis that Islamic banks are more able to survive than conventional banks. This condition is evidenced by the continued high growth of financing in the 2008/2009 recession years, from Rp. 38,195 billion in 2008 to 46,886 in 2009. (www.bi.go.id). The basic principle of Islamic Bank that puts forward the concept of profit sharing in a funding distribution agreement or fund placement makes the financial potency and risk borne by both parties namely the bank and the customer jointly. This also happens because the average bank would review all sectors of the economy causing GDP growth to be low. The bank will review what sectors must enter or need to be re-examined.

The Effect of Operational Income Operating Cost (BOPO) on Non-Performing Financing (NPF)

The result of the statistical test shows that Operational Income Operating Cost (BOPO) has a significant positive effect on Non Performing Financing (NPF), so the hypothesis is accepted. The result of this study is in accordance with the NPF theory which states that Operational Income Operational Cost (BOPO) is one of the micro variables that can affect NPF. A high BOPO value means that the costs incurred by the bank are more than the income earned, indicating that the quality of financing is poor, thus giving rise to NPF.

The result of this study also supports the previous research conducted by Lidyah (2016)Biaya Operasional Pendapatan Operasional (BOPO and Effendi et al. (2017) which state that Operating Costs Operating Income (BOPO) has a significant positive effect on Non Performing Financing (NPF). This is as the smaller the ratio of costs (expenses), the better the operation will be because the costs incurred are smaller than the income received. In other words, the higher the BOPO ratio, the quality of financing will decrease. Thus, it can also cause an increase in the ratio of non-performing financing due to reduced total financing.

\section{The Effect of Financing to Deposit Ratio (FDR) on Non Performing Financing (NPF)}

The result of statistical test shows that Financing to Deposit Ratio (FDR) has no significant effect on Non Performing Financing (NPF), so the hypothesis is rejected. This is not in accordance with the NPF theory which states that Financing to Deposit Ratio (FDR) is one of the liquidity ratios in banks. Liquidity refers to the ability of banks to meet their obligations, especially from depositors (Setyawati, Kartini, Rachman, \& Febrian, 2015). To avoid bankruptcy, banks often hold liquid assets that can be easily converted into cash (Said \& Tumin, 2011). Financing to Deposit Ratio (FDR) states how far the bank's ability to repay the withdrawal of funds by depositors by relying on loans provided as a source of liquidity. The higher this ratio, the lower the bank's liquidity capability.

The result of this study is in line with the research conducted by Firmansari \& Suprayogi (2015), Asnaini (2014) and Havidz \& Setiawan (2015)the determinants of banks efficiency and non-performing financing (NPF which state that Financing to Deposit Ratio (FDR) has no significant effect on Non-Performing Financing (NPF). The rejection of this hypothesis is likely to occur 
because FDR only best describes banks in utilizing funds collected from the public in the form of distribution of financing in order to make a profit. Then, it becomes the bank's short-term obligation to return it back to the customer who at anytime takes the funds back, so that it does not affect the NPF.

\section{The Effect of Capital Adequacy Ratio (CAR) on Non Performing Financing (NPF)}

The result of statistical test shows that Capital Adequacy Ratio (CAR) has a significant negative effect on Non-Performing Financing (NPF), so the hypothesis is accepted. The result is consistent with NPF theory which states that Capital Adequacy Ratio (CAR) is a capital ratio that shows the ability of banks to provide funds for business development needs and accommodate the possibility of loss risk arising from bank operations. The greater the ratio, the better the capital position. A large capital ratio can minimize the occurrence of NPF because the bank has sufficient loss reserves.

The result of this study also supports the previous research conducted by Lidyah (2016)Biaya Operasional Pendapatan Operasional (BOPO, Akbar (2016)dan Financing to Deposit Ratio (FDR and Sukmana (2015) which state that Capital Adequacy Ratio (CAR) has a significant negative effect on Non Performing Financing (NPF). This indicates that the greater the amount of capital owned by a bank, the smaller the chance of Non Performing Financing (NPF) receivables. The higher the capital adequacy ratio will be able to function to accommodate the risk of losses faced by banks due to increased financing problems. Thus, capital adequacy is a very important factor for banks in order to accommodate the risk of loss, especially the risk of loss for nonpayment of credit or financing.

\section{CONCLUSIONS}

The conclusions of this study are Inflation, Gross Domestic Product (GDP) and Financing to Deposit Ratio (FDR) have no significant effect on Non Performing Financing (NPF). Operational Income Operating Cost (BOPO) and Capital Adequacy Ratio (CAR) have a significant effect on Non Performing Financing (NPF).

Suggestion for further researchers can increase the independent variables of the study, including the allocation of profit sharing-based financing and the allocation of murabahah-based financing, so that Islamic banks can monitor which allocation of low risk finance and allocation of high-risk financing.

\section{REFERENCES}

Akbar, D. A. (2016). Inflasi, Gross Domestic Product (GDP), Capital Adequacy Ratio (CAR), dan Financing to Deposit Ratio (FDR) Terhadap Non Performing Financing (NPF) Pada Bank Umum Syariah Di Indonesia. I-Economic, 2(2), 19-37.

Asnaini, S. W. (2014). Faktor-Faktor Yang Mempengaruhi Non Performing Financing (NPF) Pada Bank Umum Syariah di Indonesia. Jurnal TEKUN, V(2), 264-280.

Asrori. (2014). Implementasi ICG dan Implikasinya terhadap
Kinerja Bank Syariah. Jurnal Dinamika Akuntansi, 6(1), 90-102.

Effendi, J., Thiarany, U., \& Nursyamsiah, T. (2017). Factors Influence Non Performing Financing (NPF) at Sharia Banking. Jurnal Penelitian Sosial Keagamaan Walisongo, 25(1), 109-138.

Farika, M., Achsani, N. A., \& Johan, S. (2018). The Determinant of Bank Credit Risk: Comparative Analysis of Conventional and Islamic Bank in Indonesia. European Journal of Accounting, Auditing and Finance Research, 6(3), 15-31.

Firdaus, R. N. (2015). Pengaruh Faktor Internal dan Eksternal Yang Mempengaruhi Pembiayaan Bermasalah pada Bank Umum Syariah di Indonesia. Jurnal El-Dinar, 3(1), 82-108.

Firmansari, D., \& Suprayogi, N. (2015). Pengaruh Variabel Makroekonomi Dan Variabel Spesifik Bank Terhadap Non Performing Financing Pada Bank Umum Syariah dan Unit Usaha Syariah Di Indonesia Periode 20032014. JESTT, 2(6), 512-520.

Firmansyah, I. (2014). Determinan Of Non Performing Loan : The Case Of Islamic Bank In Indonesia. Buletin Ekonomi Moneter Dan Perbankan, 17(2), 233-250.

Haifa, \& Wibowo, D. (2015). Pengaruh Faktor Internal Bank Dan Makro Ekonomi Terhadap Non Performing Financing Perbankan Syariah Di Indonesia Periode 2010-2014. Jurnal Nisbah, 1(2), 74-87.

Haryono, Y., Mohd, N., \& Hamat, M. (2016). Factors Affecting Credit Risk in Indonesian Islamic Banks. Journal of Islamic Finance, 5(1), 12-25.

Havidz, S. A. H., \& Setiawan, C. (2015). Bank Efficiency and Non-Performing Financing (NPF) in the Indonesian Islamic Banks. Asian Journal of Economic Modelling, 3(3), 61-79.

Iriani, L. D., \& Yuliadi, I. (2015). The effect of macroeconomic variables on non performance financing of Islamic Banks in Indonesia. Economic Journal of Emerging Markets, 7(2), 120-134.

Kusmayadi, D., Firmansyah, I., \& Badruzaman, J. (2017). The Impact of Macroeconomic on Non Performing Loan: Comparison Study at Conventional and Islamic Banking. Jurnal Kajian Ekonomi Dan Bisnis Islam Iqtishadia, 10(2), 59-82.

Lidyah, R. (2016). Dampak Inflasi, BI Rate, Capital Adequacy Ratio (CAR), Biaya Operasional Pendapatan Operasional (BOPO) Terhadap Non Performing Financing (NPF) Pada Bank Umum Syariah Di Indonesia. I-Finance, 2(1), 1-19.

Lin, H., Farhani, N. H., \& Koo, M. (2016). The Impact of Macroeconomic Factors on Credit Risk in Conventional Banks and Islamic Banks : Evidence from Indonesia. International Journal of Financial Research, 7(4), $105-116$.

Mutamimah, \& Chasanah, S. N. Z. (2012). Analisis Eksternal dan Internal dalam Menentukan Non Performing Financing Bank Umum Syariah di Indonesia. Jurnal Bisnis Dan Ekonomi (JBE), 19(1), 49-64.

Nasih, M. (2013). The Analysis of Non Performing Financing Determinants on Indonesian Islamic Banking. Jurnal Ekonomika Bisnis, 4(2), 171-182.

Popita, M. S. A. (2013). Analisis Penyebab Terjadinya Non Performing Financing (NPF) Pada Bank Umum Syariah Di Indonesia. Accounting Analysis Journal, 2(4), 404-412.

Raysa, S. (2013). Pengaruh CAR, FDR, ROA, BOPO, Return Pembiayaan Profit Loss Sharing, BI Rate, SBIS, DAN Size Terhadap Non Performing Financing Pada Bank 
Umum Syariah Periode 2010-2013. Skripsi Universitas Islam Negeri Sunan Kalijaga Yogyakarta.

Said, R. M., \& Tumin, M. H. (2011). Performance and Financial Ratios of Commercial Banks in Malaysia and China. International Review of Business Research Papers, 7(2), 157-169.

Sari, M. K. (2016). Determinan risiko pembiayaan bank umum syariah di Indonesia. Journal of Islamic Economics Lariba, 2(2), 55-64.

Setiawan, C., Hasan, T., Hassan, M. K., \& Mohamad, S. (2017). Non Performing Loans and Bank Efficiency of Conventional and Islamic Banks in the Organization of Islamic Cooperation ( OIC ) Countries. Journal of Islamic Economic, Banking, and Finance, 13(4), 62-81.

Setiawan, C., \& Sherwin, S. M. (2017). Banks Efficiency and the Determinants of Non-Performing Financing of Full-Fledged Islamic Banks in Indonesia. Proceedings of 12th Asia-Pacific Business Research Conference.

Setyawati, I., Kartini, D., Rachman, S., \& Febrian, E. (2015).
Assessing the Islamic Banking Financial Performance in Indonesia. International Journal of Education and Research, 3(10), 233-248.

Sukmana, R. (2015). Determinants of Non Performing Financing in Indonesian Islamic Banks. Islamic Research and Training Institute.

Suryanto. (2015). Non Performing Loans on Regional Development Bank in Indonesia and Factors that Influence. Mediterranean Journal of Social Sciences, 6(4), 280-287.

Wangsawidjaja. (2012). Pembiayaan Bank Syariah. Jakarta : PT Gramedia Pustaka Utama.

Yasin, A., \& Widiastuti, T. (2014). Determinan Non Performing Financing (NPF) Pada Bank Pembiayaan Rakyat (BPR) Syariah di Indonesia. Ekonomi, Manajemen, Dan Akuntansi Islam IMANENSI, 2(1), 1-67.

Yulianto, A., \& Solikhah, B. (2016). The Internal Factors of Indonesian Sharia Banking to Predict The Mudharabah Deposits. Review of Integrative Businesss \& Economic, 5(1), 210-218. 